\title{
Gerentological Studies on the Gross and Histomorphology of the Vesicular Gland of Gaddi Goat (Capra hircus)
}

\author{
Estudios Gerontológicos en Anatomía e Histomorfología de la \\ Glándula Vesicular de Cabra Gaddi (Cabra hircus)
}

Archana, P.; Katiyar, R. S.; Sharma, D. N. \& Farooqui, M. M.

\begin{abstract}
ARCHANA, P.; KATIYAR, R. S.; SHARMA, D. N. \& FAROOQUI, M. M. Gerentological studies on the gross and histomorphology of the vesicular gland of Gaddi goat (Capra hircus). Int. J. Morphol., 27(1):13-20, 2009.

SUMMARY: The study was conducted on the vesicular glands of 30 entire pure male Gaddi goats from birth to $5 y r s$ and 6 months of age, divided into three equal size groups of 10 animals in each viz; Pre-pubertal (1day old to $<18$ months of age), Pubertal (18 months to $<5$ years of age) and Post-pubertal ( $>5$ years) age groups. In new born kid the glands were small, white cord like. It became "?" shaped at 6 months and "S" shaped at 12 months of age. A significant growth in size and weight of gland occurred at 6 month, then up to 12 month and beyond it grew slowly. The secretory acini of the lobules were lined by pseudostratified ciliated columnar epithelium which contained A-tall columnar, Bbasal and C-narrow columnar type of cells. The number per unit area and size of the gland increased with age significantly from birth in the prepubertal animals and up to puberty. In post-pubertal animals it did not grow significantly, rather the connective tissue elements were increased in the capsule (adventitia). The intralobular connective tissue however, decreased at the expense of growth of acini at all ages.
\end{abstract}

KEY WORDS: Gross anatomy; Histomorphology; Gerentological changes; Vesicular gland.

\section{INTRODUCTION}

Gaddi goats are the migratory goats generally reared in the mountainous temperate zone of (1500-3000 meters MSL) North-Western India and are the sole source of livelihood of the tribals dwelling in these areas. They are dual purpose animals and are good for meat, milk, hair and wool etc. The vesicular glands are a pair of lobular accessory sex glands located at the origin of the urethra from the urinary bladder and are easily identified because of their appearance like "cluster of grapes". The work on the anatomy and histology of vesicular glands of the goats are scarcely available (Kundu, 1980; Gupta, 1989) although a few references are available in the text books on other ruminanats (Sisson, 1975; Dyce \& Wensing, 1971; Nickel et al., 1973). This paper records the sequential changes in the anatomy and histology of the vesicular gland of Gaddi goat from birth to 5 years and 6 months of age.

\section{MATERIAL AND METHOD}

The study was conducted on the vesicular glands of 30 entire pure male Gaddi goats divided into three equal size groups of 10 animals in each viz; Pre-pubertal (1day old to $<18$ months of age), Pubertal (18 months to $<5$ years of age) and Post-pubertal ( $>5$ years) age groups. The samples of male genital system were procured from the municipal slaughter house of Palampur (Himachal Pradesh, India). During the ante-mortem examination, the age of the animal was enquired from the owner and then confirmed by the teeth eruption. Five samples of one day old kid were collected from the Veterinary Clinical Complex of CSK Himachal Pradesh Krishi Vishvavidyalaya, Palampur. After detailed gross and topographic morphological examination in situ, the measurements of length (anteroposterior), width (lateromedial) and thickness (dorsoventral) of right and left vesicular glands were recorded separately of each animal 
with the help of Vernier Calipers and non stretchable nylon thread. The weight was recorded on the electronic digital weighing machine. Thin pieces of tissues were collected from the various representative areas of vesicular gland and fixed in the $10 \%$ neutral buffered formalin, formal acetic alcohol (FAA), Zenker's solution and cold acetone. The fixed tissues were processed through the alcohol - benzene schedule, infiltrated and embedded in paraffin $\left(60-62^{\circ} \mathrm{C}\right.$ melting point). Thin paraffin sections $(5 \mu \mathrm{m})$ were cut and stained with Haematoxylin and Eosin (Luna, 1968) for routine fibrocellular architecture, Van Gieson's stain (Luna) for collagen fibers, Gomori's reticulin method (Luna) for reticular fibers and Weigert's resorcin fuchsin and orcein (Luna) stain for elastic fibers. Micrometrical measurements were recorded with the help of calibrated ocular micrometer.

\section{RESULTS AND DISCUSSION}

The vesicular glands of Gaddi goats were situated on the dorso-lateral aspect of the neck of the urinary bladder and the initial part of the pelvic urethra lateral to the ampulla of the vas deferens (Figs. 1, 2) as in ox (Sisson; Nickel et al.; Dyce \& Wensing). In one day old kids, the vesicular glands were small but glandular in appearance (Fig. 1). Lobulations were indistinct. A small white cord like structure appeared at the point of union of ampulla with the urethra connecting both sides of gland. With the increase in age, the size of gland increased and lobulations on the surface became very much distinct (Fig. 1,2). At six months of age it acquired the shape of sign of interrogation (?) and at 12 months of age; became "S" shaped. Sudhakar, (1982) recorded lobulations in the tubular vesicular glands of 2 years old buffalo, while it's definitive "?" shape was attained at 4 years. Asdell (1955), Sisson described it as compact lobulated glands in bovines. Chandrapal, (1976) reported it tubular shaped with swollen ends in the neonatal and elongated with lobulations in the pubertal buffaloes. The average weight of the vesicular gland in the neonatal Gaddi goats was $0.23 \mathrm{~g}$ on left side and $0.25 \mathrm{~g}$ in on right side which became $3.80 \mathrm{~g}$ and $3.82 \mathrm{~g}$ at 12 month age, thereby indicating a $25 \mathrm{X}$ increase in weight in the later part of prepuberty. The overall mean weight of the vesicular gland in prepubertal animals was $2.35 \pm 0.26 \mathrm{~g}$ (Table I). Statistically there was no significant difference between the weight of the gland of either side at any stage of development as also reported by Kundu; Gupta et al,. (1979) in Black Bengal and Beetal goats, respectively. The weight of the gland grew at a very fast rate in the prepubertal animals and only slowly in the pubertal and post pubertal animals. The mean weight of the gland in pubertal and postpubertal animals was $3.05 \pm 0.17 \mathrm{~g}$ and $3.47 \pm 0.14 \mathrm{~g}$ respectively (Table I). The average length, width and thickness of the right vesicular gland in one day old goats were $0.96,0.59$ and $0.53 \mathrm{~cm}$ whereas the left gland measured $1.10,0.71$ and $0.54 \mathrm{~cm}$, respectively. It grew for $2-3 \mathrm{X}$ in all its dimensions in late prepubertal age. The overall mean length, width and thickness of the prepubertal gland was $2.44 \times 1.36 \times 1.06 \mathrm{~cm}^{3}$. These parameters were $2.71 \times 1.62 \times 1.31$ $\mathrm{cm}^{3}$ and $2.97 \times 2.00 \times 1.17 \mathrm{~cm}^{3}$ in pubertal and post-pubertal goats respectively (Table I). Thus indicating only approximately $50 \%$ increase in weight and size of the gland after the final attainment of maturity. The study goes in conformity with the observations of Kundu; Gupta et al., (1993). Gupta et al., recorded a faster growth rate in early age with maximum growth during the 12 th postnatal month, which later slowed down in 18-24 month.

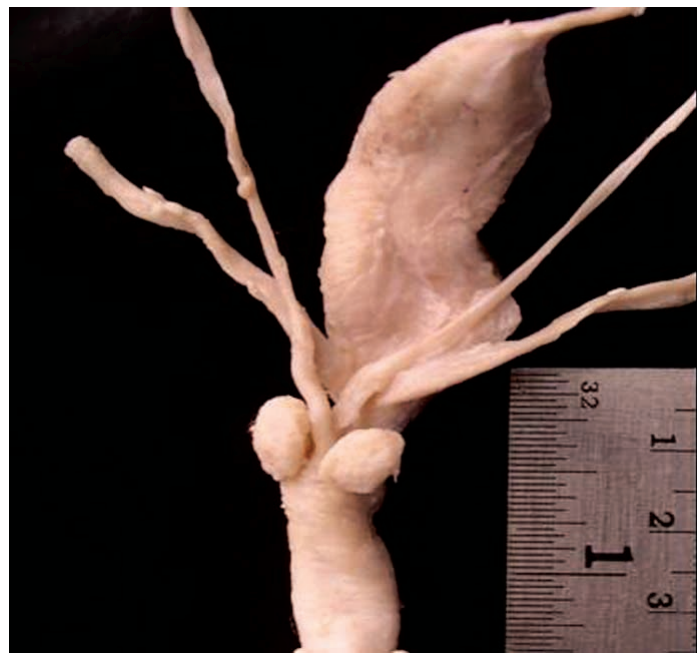

Fig. 1. Photograph of internal genital organs of a day old Gaddi kid showing ampullae (a); vesicular glands (b), pelvic urethra (c) and urinary bladder (d).

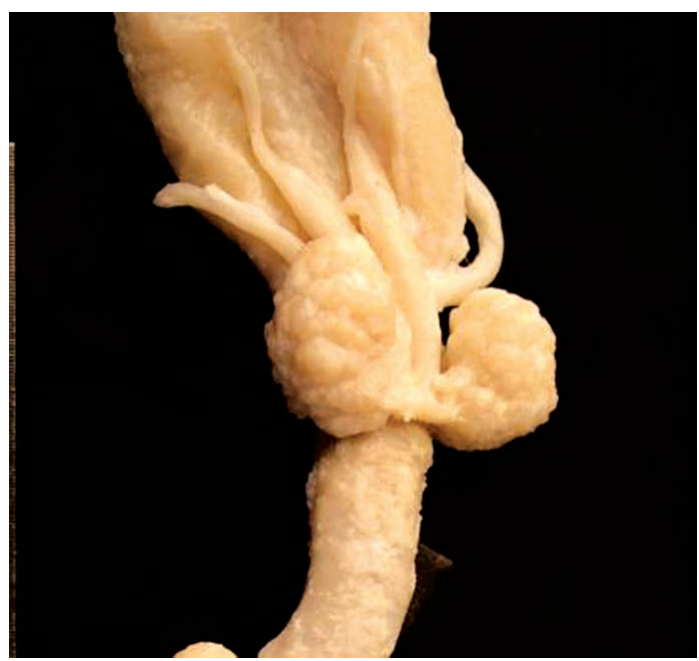

Fig. 2. Photograph of internal genital organs of pubertal Gaddi goat showing lobulated and glandular vesicular glands (a); pelvic urethra (b) and ampullae (c). 
Table I. Morphological parameters (Mean \pm S.E) of vesicular gland in Gaddi goats in various age groups. $\mathrm{n}=10$. Figures in the parenthesis indicate the range $\mathrm{a}, \mathrm{b}, \mathrm{c}$, shows the significant difference between the groups.

\begin{tabular}{clccc}
\hline S. No. & Parameter & Pre-pubertal & Pubertal & Post-pubertal \\
\hline 1. & Weight $(\mathrm{g})$ & $2.35^{\mathrm{a}} \pm 0.26$ & $3.05^{\mathrm{ab}} \pm 0.17$ & $3.47^{\mathrm{b}} \pm 0.14$ \\
& & $(0.23-3.82)$ & $(1.55-4.19)$ & $(1.80-4.10)$ \\
2. & Length $(\mathrm{cm})$ & $2.44 \pm 1.29$ & $2.71 \pm 0.14$ & $2.97 \pm 0.08$ \\
& & $(0.96-6.20)$ & $(2.08-4.10)$ & $(2.13-3.60)$ \\
3. & Width $(\mathrm{cm})$ & $1.36^{\mathrm{a}} \pm 0.07$ & $1.62^{\mathrm{a}} \pm 0.09$ & $2.00^{\mathrm{b}} \pm 0.09$ \\
& & $(0.59-1.75)$ & $(0.98-2.50)$ & $(1.32-2.80)$ \\
4. & Thickness $(\mathrm{cm})$ & $1.06^{\mathrm{a}} \pm 0.08$ & $1.31^{\mathrm{a}} \pm 0.10$ & $1.74^{\mathrm{b}} \pm 0.08$ \\
& & $(0.45-1.72)$ & $(0.80-2.50)$ & $(1.15-2.25)$
\end{tabular}

Histologically, the vesicular gland of Gaddi goats was lobulated compound tubulo-alveolar gland as described in Murrah bull (Sudhakar et al., 1986) and goats (Kundu). Each lobule of the gland showed folded tunica mucosa (117.26 $\mu \mathrm{m})$ comprising of lamina epithelialis $(23 \mu \mathrm{m})$ and lamina propria $(94.26 \mu \mathrm{m})$, tunica muscularis $(29.4 \mu \mathrm{m})$ and tunica adventitia $(35.28 \mu \mathrm{m})$ in one day old kids (Fig. 3). Similar description has been given by Trautmann \& Fiebiger, (1957), Chandrapal; Dellmann \& Wrobel, (1976); Sudhakar in other domestic animals. The central collecting sinus of each lobule was lined with pseudostratified columnar epithelium. Three types of cells have been identified viz; A, B and C as described earlier in goat (Yao \& Eaton, 1954; Wrobel, 1970; Gupta \& Singh, 1982 ; Ploen, 1980; Gupta, 1989) sheep (Skinner et al., 1968; Singh et al., 1980) and buffalo (Chandrapal; Sudhakar). A-type cells were tall columnar bottle like in shape with distinct cell boundaries. In one day old kids such cells measured $20.43 \mu \mathrm{m}$ in height and 4.54 $\mu \mathrm{m}$ in width. Their vacuolated cytoplasm was finely granular and slightly basophilic in nature in the apical region. The nuclei were ovoid and their average height and width measured $5.68 \mu \mathrm{m}$ and $4.54 \mu \mathrm{m}$, respectively. It contained evenly distributed fine chromatin. In the goats of late prepubertal stages ( 12 months to $<18$ months) these cells contained eosinophilic cytoplasm which stained relatively more darkly in the apical region. The average height of these cells measured $36.11 \mu \mathrm{m}$ and $8.39 \mu \mathrm{m}$ in width in prepubertal animals. B-type cells were spherical in shape and placed basally. The outlines of these cells were not distinct and their cytoplasm was clear. The centrally placed nuclei were either round or oval. The round nuclei were smaller than those of "A" cells and measured $4.34 \mu \mathrm{m}$ in diameter. The oval nuclei measured $4.54 \mu \mathrm{m}$ and $3.41 \mu \mathrm{m}$ in height and width, respectively. It contained finely granular chromatin with occasionally more than one nucleoli. In the late pre-pubertal goats, these cells measured on an average $22.25 \mu \mathrm{m}$ in height and $7.49 \mu \mathrm{m}$ in width. C-type cells were narrow columnar cells with darkly stained cytoplasm and hyperchromic nuclei. These cells were fewer in number as compared to " $A$ " and "B" type cells. In one day old kids, these cells measured
$18.16 \mu \mathrm{m}$ in height and $4.54 \mu \mathrm{m}$ in width. These cells contained more basophilic, homogeneous cytoplasm. Their narrow nuclei stained intensely with Haematoxylene and appeared dark bluish. They took a strong tinge of reddish when stained with trichrome stain. These were packed with finely granular chromatin. In late pre-pubertal animals, Ctype cells measured $20.16 \mu \mathrm{m}$ in height and $6.81 \mu \mathrm{m}$ in width and had similar cytological characters as in one day old kids. The nuclei were narrow and elongated and measured 6.81 $\mu \mathrm{m}$ in height and $4.54 \mu \mathrm{m}$ in width. All the three types of cells i.e. $\mathrm{A}, \mathrm{B}$ and $\mathrm{C}$ as described in the pre-pubertal animals were also demonstrated in the pubertal and post-pubertal animals. They contained eosinophilic, vacuolated cytoplasm. The vesicular nuclei were spherical to ovoid in shape and contained more peripherally distributed chromatin. However, the number of "C"-type cells was relatively fewer in pubertal animals, which further decreased in the post-pubertal animals.

It is concluded that the A cells were the chief secretory cells, B cells were the basal reserve cells and C cells were structurally and functionally compressed cells between the A cells. Similar contentions regarding these cells have been held by earlier authors (Cons, 1957; Bhardwaj, 1960; Chandrapal; Gupta 1989; Sudhakar) in different species of animals.

Lamina propria: The lamina propria comprised of loose areolar connective tissue containing secretory end pieces with varying number of alveoli. In one day old kids, the glands were only a few in numbers per unit area and the inter-glandular connective tissue was preponderant (Fig. 3). With the advancement of age, the number of alveoli per unit area increased and the amount of inter-glandular connective tissue stroma was reduced. The fibro-architectural design comprised of the circularly arranged collagenous fibrous bundles with reticular fibers (Fig. 4). The elastic fibers also occurred in the intralobular connective tissue (Fig. 5). The average thickness of lamina propria in one day old kid was $23 \mu \mathrm{m}$, while in pre-pubertal goats it became $30.38 \mu \mathrm{m}$ thick. 


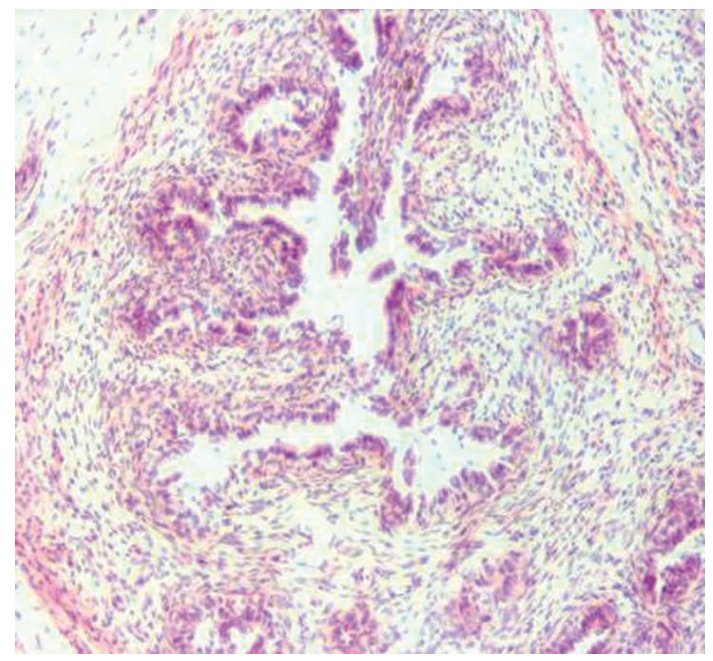

Fig. 3. Photomicrograph of vesicular gland of one day old kid showing a lobule with central cistern (a), branching duct (b) and differentiating acini (c) in the surrounding connective tissue. H \& E. X 100.

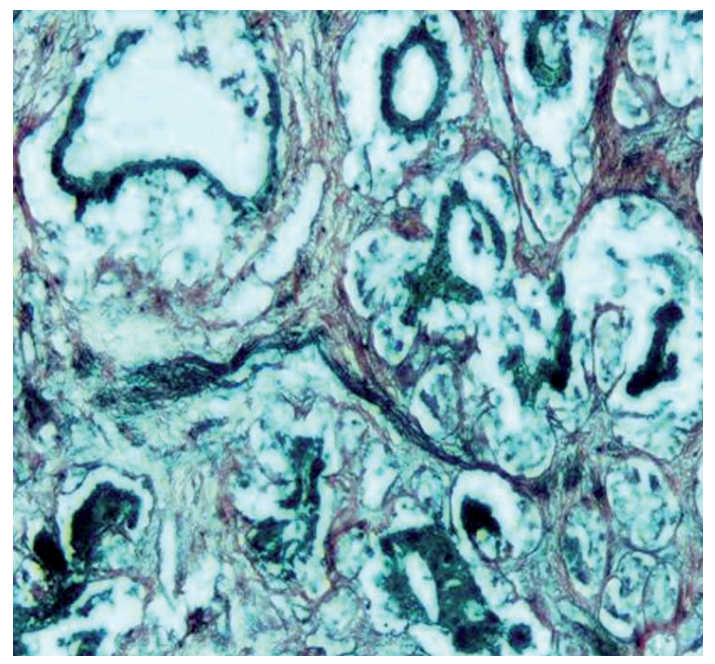

Fig. 5. Photomicrograph of vesicular gland of one day old kid showing trabeculae rich in elastic fibers (a). Weigert's resorcin fuchsin stain. X 100.

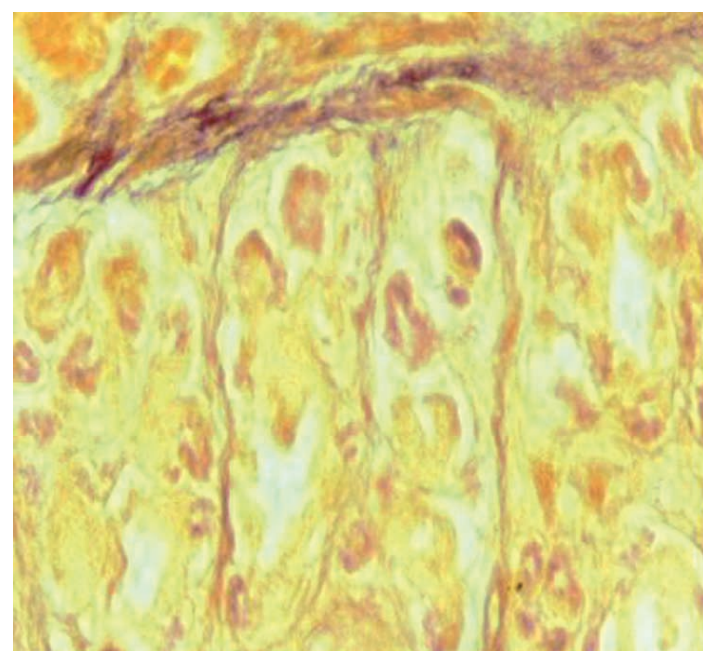

Fig. 7. Photomicrograph of vesicular gland from post-pubertal Gaddi goat showing concentrated fenestrated network of reticular fibers around the acini. Gomori's reticulin. X 100.

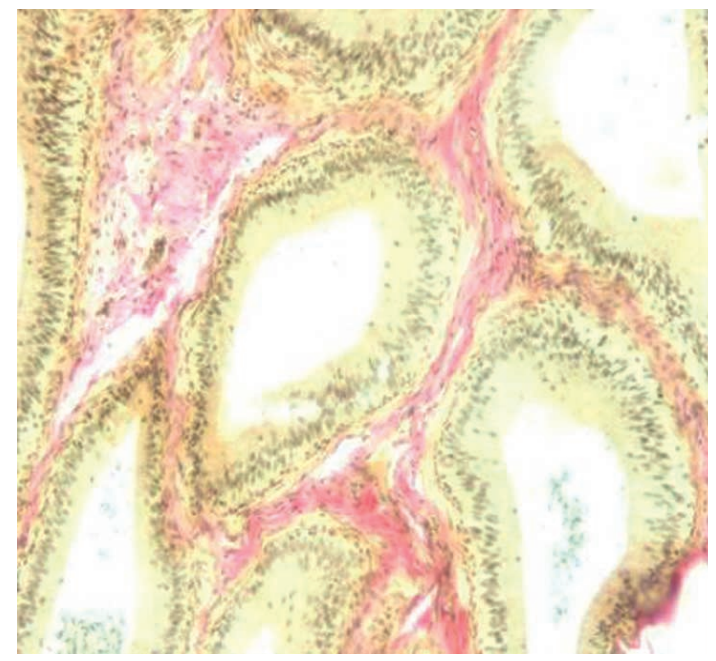

Fig. 4. Photomicrograph of vesicular gland of one day old kid showing highly argyrophilic reticular fibers in the basement membrane and fine reticular fibers in the lamina propria. Gomori's reticulin stain. X 100.

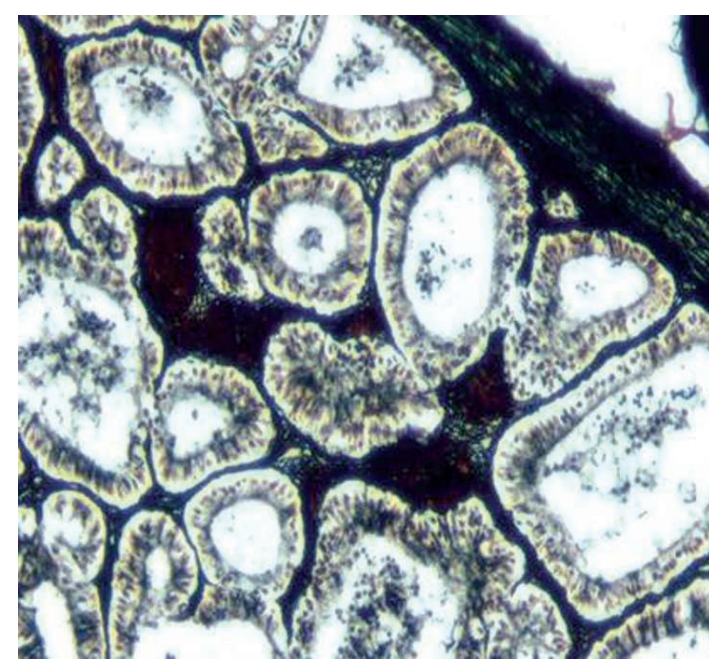

Fig. 6. Photomicrograph of vesicular gland from post-pubertal Gaddi goat showing extremely reduced collagenous fibers in the intralobular connective tissue (a).Van Gieson's stain. X 100.

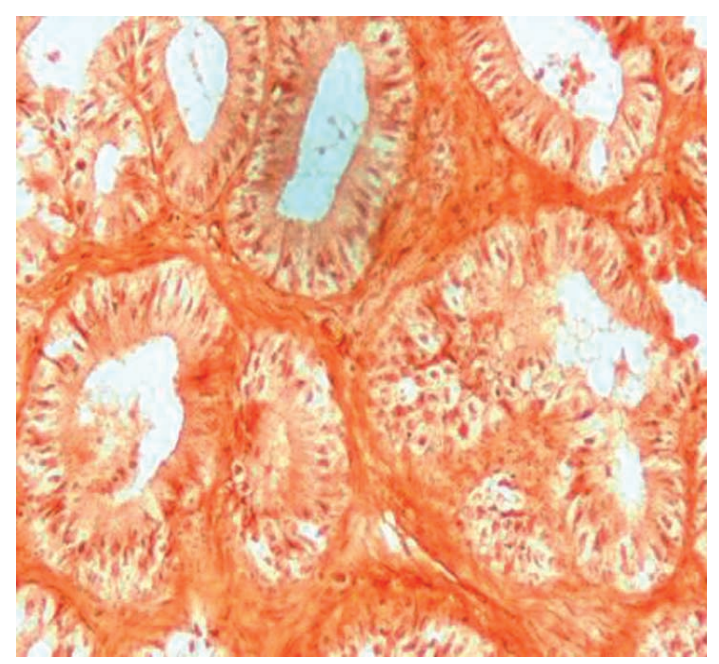

Fig. 8.Photomicrograph of vesicular gland from post-pubertal Gaddi goat showing elastic fibers in the periacinar connective tissue (a). Orcein. X 200. 
With the advancement of age, the collagenous and reticular fibers became coarser (Figs. 6 and 7). Irregularly distributed elastic fibers were also recorded in the pubertal and postpubertal animals (Fig. 8).

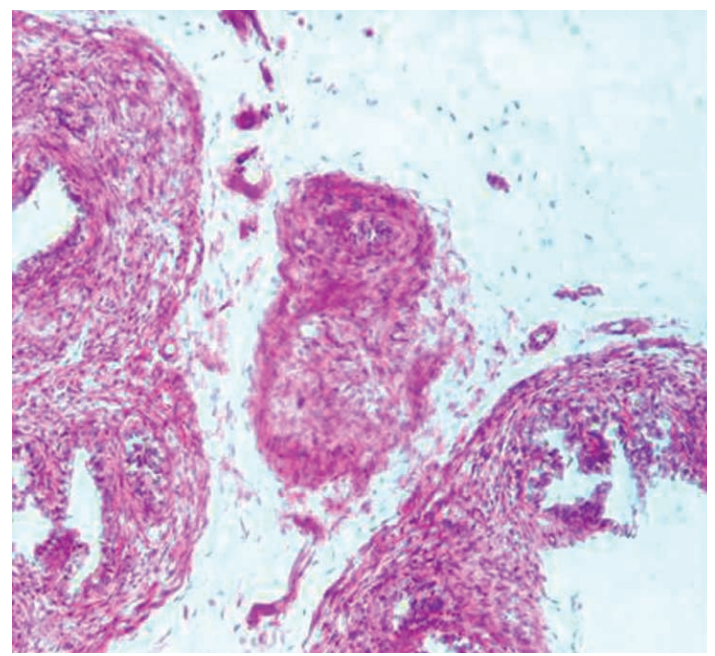

Fig. 9. Photomicrograph of vesicular gland of one day old kid showing nerve bundles(a) along with the arteriole (b) with epitheloid cell formation of cells of muscularis. PAS. X 100.
Glands: The glands were compound tubulo-alveolar type as described in Beetal goats (Gupta, 1989) and buffalo (Chandrapal; Sudhakar). Some of these glands appeared luminated while others were non-luminated. In one day old kids the average diameter of the luminated glandular end pieces was $67.07 \mu \mathrm{m}$ while the non luminated glandular end pieces measured $51.53 \mu \mathrm{m}$. The number of glands increased per unit area in pre-pubertal goats. At this stage, the average diameter of luminated glandular end pieces measured 124.91 $\mu \mathrm{m}$ while the non-luminated glandular end pieces measured $111.41 \mu \mathrm{m}$ in diameter (Table II). In pubertal and postpubertal animals, the average diameter of luminated acini was $193.72 \pm 3.41 \mu \mathrm{m}$ and $193.84 \pm 2.86 \mu \mathrm{m}$, respectively and the non-luminated acini were $169.59 \pm 3.45 \mu \mathrm{m}$ and $166.96 \pm 2.47 \mu \mathrm{m}$, respectively (Table II).

The glandular end pieces of the vesicular glands of Gaddi goats were lined by pseudostratified columnar epithelium. Occasionally, simple cuboidal or simple columnar epithelium was also encountered particularly when the alveoli were dilated. Similar to the epithelial lining of the mucosa, the glands also consisted of tall columnar Atype cells, short basal B type cells and narrow C-type cells.

Table II.Micrometrical parameters of the various componenets of vesicular gland in Gaddi goats of various age groups. Values of ten observations each of ten animals in each group. Figures in the parenthesis indicate the range. a, b, c, shows the significant difference between the groups.

\begin{tabular}{|c|c|c|c|c|}
\hline S. $\mathbf{N}^{\mathbf{0}}$. & Parameters ( $\mu \mathrm{m})$ & Pre-pubertal & Pubertal & Post-pubertal \\
\hline \multirow[t]{2}{*}{1.} & Thickness of tunica adventitia & $65.36^{\mathrm{a}} \pm 6.89$ & $164.05^{\mathrm{b}} \pm 7.19$ & $207.27^{c} \pm 5.45$ \\
\hline & & $(35.28-101.92)$ & (125.44-192.08) & $(184.24-232.26)$ \\
\hline \multirow[t]{2}{*}{2.} & Thickness of tunica muscular is & $78.20^{\mathrm{a}} \pm 9.01$ & $210.11^{\mathrm{b}} \pm 7.01$ & $269.79^{c} \pm 4.30$ \\
\hline & & $(29.40-125.44)$ & $(174.44-237.16)$ & $(242.06-287.14)$ \\
\hline \multirow[t]{2}{*}{3.} & Thickness of interstitial tissue & $21.91^{\mathrm{b}} \pm 3.20$ & $11.94^{\mathrm{a}} \pm 0.10$ & $8.33^{\mathrm{a}} \pm 0.36$ \\
\hline & & $(12.25-43.35)$ & $(11.57-12.71)$ & $(5.67-9.30)$ \\
\hline \multirow[t]{7}{*}{4.} & Glandular end pieces & & & \\
\hline & a) Diameter of luminated acini & $124.91^{\mathrm{a}} \pm 10.79$ & $193.72^{\mathrm{b}} \pm 3.41$ & $193.84^{\mathrm{b}} \pm 2.86$ \\
\hline & & $(67.07-166.85)$ & $(180.01-213.83)$ & $(183.87-209.98)$ \\
\hline & b) Diameter of non-luminated acini & $111.41^{\mathrm{a}} \pm 9.12$ & $169.59^{\mathrm{b}} \pm 3.45$ & $166.96^{\mathrm{b}} \pm 2.47$ \\
\hline & & $(51.53-149.14)$ & $(157.08-187.50)$ & $(160.26-181.42)$ \\
\hline & c) Epithelial height & $19.70^{\mathrm{a}} \pm 0.86$ & $24.97^{\mathrm{b}} \pm 0.21$ & $25.24^{c} \pm 0.12$ \\
\hline & & $(15.44-24.06)$ & $(23.84-26.11)$ & $(24.52-25.88)$ \\
\hline \multirow[t]{5}{*}{5.} & Duct & & & \\
\hline & a) Diameter of duct & $58.45^{\mathrm{a}} \pm 4.99$ & $119.81^{\mathrm{b}} \pm 5.46$ & $140.08^{c} \pm 0.83$ \\
\hline & & $(43.36-90.34)$ & $(96.48-142.10)$ & $(136.65-143.69)$ \\
\hline & b) Epithelial height & $13.05^{\mathrm{a}} \pm 0.49$ & $19.83^{\mathrm{b}} \pm 0.29$ & $21.45^{\mathrm{c}} \pm 0.21$ \\
\hline & & $(11.35-16.79)$ & $(18.38-20.88)$ & $(20.43-22.24)$ \\
\hline
\end{tabular}


The cytological characters of these cells and their nuclei were almost similar to those as observed in the lining epithelium of tunica mucosa. On an average the height and width of these cells in luminated acini were 19.70 and $7.49 \mu \mathrm{m}$, respectively in prepubertal animals. The nuclei were rounded, oval or elongated in shape with an average height of $7.04 \mu \mathrm{m}$ and width of 4.09 $\mu \mathrm{m}$. The size of the gland increased with age significantly from birth in the prepubertal animals and up to puberty. In post-pubertal animals it did not grow very significantly. The secretary end pieces of the vesicular glands of Gaddi goats, exhibited apocrine mode of secretion. The glands were surrounded by a connective tissue layer which contained collagen and reticular fibers in all pre-pubertal animals.

Ducts: The central collecting sinus (Fig. 3) of each lobule united to form the interlobular duct. The union of several such ducts, in turn formed the main excretory duct of the vesicular gland. The interlobular and main excretory ducts contained folded mucosa which was lined by pseudostratified columnar epithelium in one day old kids. In goats of later stages of pre-pubertal age, the epithelium was composed of three types of cells viz; Surface columnar cells, were columnar in shape placed more towards the lumen and had eosinophilic cytoplasm. They had compact contracted nuclei with condensed chromatin material. Wedging plumpy columnar/cylindrical cells were columnar in shape, with cylindrical or elongated oval nuclei. One or two nucleoli placed eccentrically. Central matrix of the nucleus was almost homogeneously clear. The chromatin was tucked up all along their nuclear membrane. Basal cells were rounded in shape with clear cytoplasm. On the basis of morphology of nucleus these were of two kinds. One was with round or slightly dorsoventrally flattened nuclei. Many of these cells showed clumping of the chromatin in the center or were in the process of division (metaphasic/ anaphasic stage). The other cells were with spherical nucleus and their chromatin was distributed evenly.

A review of the data on the micrometry of parenchymatous elements revealed a drastic increase in the diameter of ducts $(100 \%)$, luminated secretory end pieces $(50 \%)$, the non-luminated secretory end pieces and the epithelial height of the acini (40\%) and ducts $(50 \%)$ during passage from pre-pubertal to pubertal stages. The acinar parameters did not change significantly after puberty, although the ductal parameters improved only slightly during the animal's transition from puberty to post-puberty. This clearly indicated that the growth of actual secretory components i.e. acini was completed when the animal attains puberty. After this it did not grow structurally and so also functionally. This goes in conformity of the observations of Gupta (1989) who also reported significant growth in the acinar diameter and lining epithelium of the vesicular glands of Beetal goats particularly at 12 month of age after which it maintained a plateau. Naidu \& Pattabhiraman (2001) reported an increase in the size of alveoli and decrease in the epithelial height of the lumen of the vesicular glands of 7-8 month old Madras red ram lambs.

The tunica muscularis surrounded each lobule of the vesicular gland. It was composed of a thick layer of interwoven smooth muscle fibers. In one day old kids, inner circular and outer longitudinal or oblique layers were distinct and the same pattern was observed in pre-pubertal goats. The average thickness of muscular layer in one day old kids was $29.40 \mu \mathrm{m}$ and its thickness increased with the advancement of age. In pre-pubertal goats its average thickness measured $78.20 \mu \mathrm{m}$ (Table II).

The tunica adventitia was comprised of loosely arranged meshwork of collagen, reticulin and elastin fibers as reported in goats (Gupta, 1978) and buffalo (Sudhakar et al). Many blood vessels, nerve fibers and autonomic ganglion were seen in the tunica adventitia (Fig. 9). It measured $35.28 \mu \mathrm{m}$ in thickness in one day old kids. In pre-pubertal animals its average thickness was $65.36 \mu \mathrm{m}$ (Table II).

The micrometrical data revealed a continuous and progressive increase in the tunica adventitia of the gland from pre-pubertal to pubertal stage $(2.5 \mathrm{X}$ increment) and then to post-pubertal stage (only $25 \%$ increment over the preceding stage) (Table II). The continuous increase in the thickness of tunica albuginia with age was also reported by Sudhakar. The tunica muscularis also reflected a similar trend of growth. But a just reverse trend occurred when the data on interstitial tissue was considered where it became just half of the prepubertal stage in pubertal animals (100\% reduction) and about $2 / 3^{\text {rd }}$ (70\% reduction) in post pubertal stage. Thus it was clearly evident that the thickness of the tunica adventitia and muscularis grew with age while the interstitial tissue shrunk correspondingly. The change was more vigorous between the prepubertal to pubertal stage than between pubertal to post-pubertal stage. Similar trend of growth of capsule, interlobular septa and interstititial tissue of the vesicular glands have been reported in Beetal goats (Gupta, 1989) and ram (Singh et al.). 
ARCHANA, P.; KATIYAR, R. S.; SHARMA, D. N. \& FAROOQUI, M. M. Estudios gerontológicos en anatomía e histomorfología de la glándula vesicular de cabra Gaddi (Capra hircus). Int. J. Morphol., 27(1):13-20, 2008.

RESUMEN: Se realizó un estudio de las glándulas vesiculares de 30 cabras Gaddi, macho, totalmente puras desde el nacimiento hasta los 5 años y 6 meses de edad, divididas en tres grupos de 10 animales cada uno, pre-puberal (día 1 de edad a $<18$ meses de edad), pubertad (18 meses a $<5$ años de edad) y post-puberal ( $>5$ años). En el recién nacido las glándulas eran pequeñas, como un cordón blanco. Se presentó en forma de "?" a los 6 meses y de "S" a los 12 meses de edad. Un importante crecimiento en tamaño y peso de la glándula se produjo a los 6 meses, luego de 12 meses y más, creció lentamente. Los acinos secretores de los lóbulos se alinearon como epitelio columnar ciliado pseudoestratificado, los cuales contienen celulas de tipo A-columnar alto, B-basal y C-columnar estrecho. El número por unidad de área y el tamaño de la glándula aumentó significativamente con la edad desde su nacimiento en los animales prepúberes y hasta la pubertad. En animales post-puberales no creció significativamente, y los elementos del tejido conectivo se incrementaron en la cápsula (adventicia). Sin embargo, el tejido conectivo intralobular, disminuyó a expensas del crecimiento de los acinos, en todas las edades.

PALABRAS CLAVE: Anatomía; Histomorfología; Cambios Gerentológicos; Glándula vesicular.

\section{REFERENCES}

Asdell, S. A. Cattle fertility and sterility. Boston Lillie, Brown \& Company, Toronto, 1955.

Bhardwaj, M. B. L. Histology of the urethra and accessory sex glands in the domestic animals and observations on the surgical insertion of the urinary bladder neck into descending colon in the dog. Ph.D. Thesis, Michigan State University, East Lancing, USA, 1960.

Chandrapal. Gross histological and histochemical studies on the male genital system of buffalo (Bubalus bubalis). Ph.D. Thesis. Agra University, Agra. 1976.

Cons, D. N. Some observations on the histology and histochemistry of the seminal vesicles of bulls. $J$. Endocrinol., 14:304-8, 1957.

Dellman, H. D. \& Wrobel, K. H. Male reproductive system. InText book of Veterinary Histology. Ed. Dellman, $\mathrm{H}$. D. \& Brown, E. H. Lea \& Febiger, Philadelphia, 1976. p.p. 306-11.

Dyce, K. M. \& Wensing, C. J. G. Essentials of Bovine Anatomy. Lea \& Febiger, Philadelphia, 1971.

Gupta, A. N. Correlative Anatomy of the testes, epididymis \& accessory sex glands in goat. Ph.D Thesis, HAU Hisar, 1989.

Gupta, A. N. Histological and histochemical studies on the accessory genital glands of normal and castrated bucks. M.V.Sc. thesis. Haryana Agricultural University Hisar, 1978.
Gupta, A. N. \& Singh, Y. Effect of castration on the cytology of vesicular glands in goat. Indian J. Anim. Sci., 52:72-9, 1982.

Gupta, A. N., Singh, Y. \& Dhingra, L. D. Effect of castration on the morphology of vesicular gland in goat. Haryana Veterinarian. XVIII:117-20, 1979.

Gupta, A. N.; Singh, Y. \& Goyal, K. C. Morphometery of vesicular gland in relation to age and testicular growth in goat. Haryana Agricultural University Journal of Research, 23:69-72, 1993.

Kundu, P. B. Anatomical studies on the accessory male sex glands (gross and microscopic) of the Indian goat (Jamunapari and cross Jamunapari). Indian J. Anim. Health, 19:151-3, 1980.

Luna, L. G. Manual of Histological staining methods of the armed Forces Institute of pathology. $3^{\text {rd }} \mathrm{ed}$. McGraw hill Book Company, New York, 1968. pp.38, 80, 87, 145, 157, $158 \& 163$.

Naidu, K. V. \& Pattabiraman, S. R. Postnatal development of seminal vesicle in Madras Red ram lambs maintained under different feeding system. Indian J. Anim. Reprod. 22:154-8, 2001.

Nickel, R.; Schummer, A.; Seiferle, E. \& Sack, W. O. The viscera of the domestic mammals. Verlag Paul Parey Berlin. Hamburg, 1973. pp.304-48.

Ploen, L. Electron microscopic observations on the epithelium of ram seminal vesicles. J. Anat., 130:507-11, 1980. 
ARCHANA, P.; KATIYAR, R. S.; SHARMA, D. N. \& FAROOQUI, M. M. Gerentological studies on the gross and histomorphology of the vesicular gland of Gaddi goat (Capra hircus). Int. J. Morphol., 27(1):13-20, 2009.

Singh, Y.; Singh, S. P. \& Lohan, I. S. Histological and histochemical studies on the gonadotrophin treated vesicular glands of prepubertal rams. Indian J. Exp. Biol., 18:71922, 1980.

Sisson, S. In: Geity, R. (ed) Sisson \& Grossman's The Anatomy of the Domestic Animals. $5^{\text {th }}$ ed. Vol. I. W.B. Saunders Co. Philadelphia, 1975. pp.768-9.

Skinner, J. D.; Booth, W. D.; Rawson, L. E. A. \& Karg, H. Postnatal development of the reproductive tract of Suffolk ram and changes in the gonadotrophin control of the pituitary. J. Reprod. Fert., 16:463-77, 1968.

Sudhakar, L. S. Histological and histochemical changes in the male accessory genital glands of Murrah buffalo during postnatal development. Ph.D. Thesis. Haryana Agricultural University, Hisar, 1982.

Sudhakar, L. S. Dhingra L. D \& Sharma D. N. Postnatal histomorphology of the vesicular gland in Murrah buffalo bull. Indian J. Anim. Sci., 56: 866-9, 1986.

Trautmann, A. \& Fiebiger, J. Fundamentals of histology of domestic animals. Translated and revised by Habel, R. E. \& Bibertein, S. L. Comstock Publishing Associates. Ithaca, 1957. pp.269-72.

Wrobel, K. H. Morphology of the epithelium of seminal vesicles in the goat. Zentbl. Vet. Med., 17:634-43, 1970.

Yao, T. S. \& Eaton, O. N. Postnatal growth and histological development of the reproductive organs in male goats. Am. J. Anat., 95:401-31, 1954.
Correspondence to:

Dr. Archana Pathak

Associate professor and Head

Division of Anatomy and Histolgy

Faculty of Veterinary Sciences and Animal Husbandry

Sher-e- Kashmir University of Agricultural Sciences and Technology-Jammu

R.S.Pura-181102

INDIA

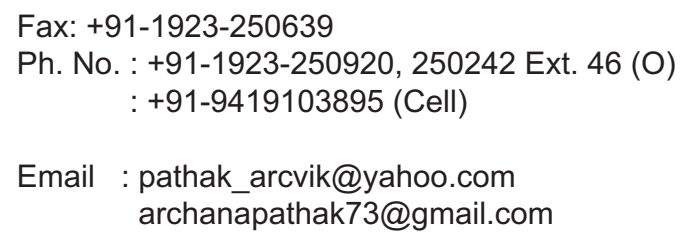

Received: 17-12-2007

Accepted: 22-06-2008 